\title{
Kesulitan Belajar Bahasa Inggris: Tidak Dipergunakan Sehari-hari
}

\section{Nanang Bagus Subekti}

Versi online: https://englishjogja.com/blog/view/9584/kesulitan-belajar-bahasa-inggris-tidakdipergunakan-sehari-hari

Bahasa Inggris bukan merupakan bahasa resmi (official language) di Indonesia, tetapi sebagai bahasa asing. Masyarakat Indonesia selain berbahasa Indonesia, sebagian besar juga menguasai bahasa daerah. Seperti saya sendiri, di samping berbahasa Indonesia saya juga berbahasa Jawa bahkan dalam kehidupan sehari-hari lebih banyak menggunakan bahasa Jawa.

Suatu bahasa akan berkembang dengan baik karena dipergunakan dalam kehidupan sehari-hari. Mahasiswa luar Jogja yang datang ke Yogyakarta sebagian besar tidak memahami bahasa Jawa. Tahun pertama kuliah mungkin menjadi masa-masa tersulit karena mereka akan mendengar dan melihat orang Jogja sering mencampur bahasa Jawa dengan bahasa Indonesia dalam percakapan sehari-hari.

Namun, seiring dengan waktu para mahasiswa luar Jogja akan memahami bahasa Jawa dan lambat laun akan bisa berbahasa Jawa dengan lancar karena mereka menjumpai bahasa Jawa dalam kehidupan sehari-hari. Tanpa disadari, mendengarkan bahasa Inggris dalam kehidupan sehari-hari adalah proses pembelajaran suatu bahasa secara alami. Nah, bagaimana dengan bahasa Inggris yang sudah dipelajari di sekolah selama kurang lebih 6 tahun?

Secara formal siswa-siswa di Indonesia telah berlajar bahasa Inggris minimal 6 tahun, 3 tahun saat dibangku SMP/MTs dan 3 tahun saat dibangku SMA/SMK. Namun, bagaimana hasilnya? Apakah para lulusan SMA/SMK bisa berbahasa Inggris dengan baik secara lesan dan tertulis? Secara umum kita mengetahui jika kemampuan bahasa Inggris orang Indonesia rendah. Mengapa hal ini bisa terjadi?

Salah satu permasalahan yang dihadapi oleh orang Indonesia adalah bahasa Inggris tidak dipergunakan dalam kehidupan sehari-hari. Bahasa Inggris dipelajari sebatas sebagai suatu mata pelajaran wajib pendidikan formal atau dengan kata lain bahasa Inggris diajarkan karena 
diberikan dalam kurikulum sebagai mata pelajaran, bukan suatu kebutuhan untuk memenuhi tuntutan untuk komunikasi sehari-hari di masyarakat. Hal ini berbeda dengan orang asing yang tinggal di negara-negara berbahasa Inggris yang harus menguasai bahasa Inggris supaya bisa berkomunikasi / berinteraksi sehari-hari. Jika kondisi seperti ini terus berlangsung, maka kemampuan bahasa Inggris orang Indonesia tidak akan mengalami perubahan, yang seperti yang sudah kita ketahui selama ini.

Subekti dan Lawson (2007) di sebuah artikel ilmiah tentang pengusaan kosakata bahasa Inggris menjelaskan jika penguasaan kosakata bahasa Inggris dipengaruhi oleh waktu. Artinya, semakin lama suatu kosakata tidak dipergunakan, maka semakin cepat hilang dari memori (ingatan) dan semakin sering dipakai pakai akan semakin kuat tersimpan dalam memori. Hal ini juga bisa dijumpai dalam 4 kemampuan berbahasa listening, speaking, reading dan writing. Misalnya, semakin sering kita berbicara bahasa Inggris maka semakin baik (fluent) kemampuan berbicaranya, sebaliknya semakin jarang berbicara dengan bahasa Inggris, semakin susah berkurang kemampuan berbicaranya.

Salah satu solusi yang bisa dilakukan adalah membumikan / mengintegrasikan Bahasa Inggris dalam rutinitas sederhana sehari hari dan membangun.Misalnya, dengan sering membaca berbagai berita dalam bahasa Inggris baik online maupun cetak, mendengarkan lagu-lagu berbahasa Inggris, menonton film-film berbahasa Inggris, membuat forum-forum / komunitas berbahasa Inggris, dll. Cara-cara sederhana inilah yang bisa kita lakukan supaya kita bisa merasakan manfaat bahasa Inggris secara langsung dan terus belajar bahasa Inggris sehingga kemampuan bahasa Inggris meningkat.

Semoga tulisan pendek ini bermanfaat.

\section{Reference (Referensi)}

1. Subekti, N. B., \& Lawson, M. J. (2007). Vocabulary acquisition strategies of Indonesian postgraduate students through reading. International Education Journal, 8(2), 485-496. 